\title{
Functional activity of the cannabinoid 1 receptor is not affected by opioid antagonists in the rat brain
}

\author{
Heeseung Lee \\ Department of Anesthesiology and Pain Medicine, School of Medicine, Ewha Womans University, Seoul, Korea
}

Background: WIN55212-2 is a synthetic cannabinoid agonist and selective to cannabinoid 1 (CB1) receptors, which are distributed mainly in the central nervous system. Opioid receptors and CB1 receptors have several similarities in terms of their intracellular signal transduction mechanisms, distributions, and pharmacological action. Several studies have therefore sought to describe the functional interactions between opioids and cannabinoids at the cellular and behavioral levels. The present study investigated agonist-stimulated $\left[{ }^{35} \mathrm{~S}\right] \mathrm{GTP} \gamma \mathrm{S}$ binding by WIN552122 in rat brain membranes and determined the antagonism by selective opioid antagonists at the level of receptorligand interaction and intracellular signal transduction.

Methods: Sprague-Dawley rats (male, $\mathrm{n}=20$ ) were euthanized for the preparation of brain membranes. In agoniststimulated $\left[{ }^{35} \mathrm{~S}\right] \mathrm{GTP} \gamma \mathrm{S}$ binding by WIN55212-2, the values of $\mathrm{EC}_{50}$ and maximum stimulation (\% over basal) were determined in the absence or presence of the $\mu, \kappa$ and $\delta$ opioid receptor antagonists naloxone $(20 \mathrm{nM})$, norbinaltorphimine $(3 \mathrm{nM})$, and naltrindole $(3 \mathrm{nM})$, respectively. Ke values for opioid antagonist inhibition in the absence or presence of each opioid receptor antagonist were calculated using the following equation: [nanomolar antagonist] / (dose ratio of $\left.\mathrm{EC}_{50}-1\right)$.

Results: In WIN55212-2-stimulated $\left[{ }^{35} \mathrm{~S}\right] \mathrm{GTP} \gamma \mathrm{S}$ binding in the rat brain membranes, the values of $\mathrm{EC}_{50}$ and maximum stimulation (\% over basal) were $154 \pm 39.5 \mathrm{nM}$ and $27.6 \pm 5.3 \%$ over basal, respectively. Addition of selective opioid antagonists did not produce a significant rightward shift in the WIN55212-2 concentration-response curve, and Ke values were not applicable.

Conclusions: Our results suggest that the functional activity of WIN55212-2-stimulated $\left[{ }^{35} \mathrm{~S}\right] \mathrm{GTP} \gamma \mathrm{S}$ binding was not affected by opioid antagonists in the rat brain membranes. Although the exact mechanism remains unclear, our results may partially elucidate their actions. (Korean J Anesthesiol 2013; 64: 257-261)

Key Words: GTP binding, Opioid antagonist, Rat brain, WIN55212-2.

\footnotetext{
Received: September 21, 2012. Revised: 1st, October 11, 2012; 2nd, October 22, 2012. Accepted: October 22, 2012.

Corresponding author: Heeseung Lee, M.D., Department of Anesthesiology and Pain Medicine, School of Medicine, Ewha Womans University, 911-1, Mok5-dong, Yangcheon-gu, Seoul 158-710, Korea. Tel: 82-2-2650-2670, Fax: 82-2-2655-2924, E-mail: leehee@ewha.ac.kr

(c) This is an open-access article distributed under the terms of the Creative Commons Attribution Non-Commercial License (http:// creativecommons.org/licenses/by-nc/3.0/), which permits unrestricted non-commercial use, distribution, and reproduction in any medium, provided the original work is properly cited.
} 


\section{Introduction}

WIN55212-2 is a synthetic cannabinoid agonist and is selective to the cannabinoid 1 (CB1) receptors, which is distributed mainly in the central nervous system. Opioid receptors and CB1 receptors have several similarities. CB1 receptors, like opioid receptors, are a member of the $\mathrm{G}$ protein-coupled receptor (GPCR) family, and their mechanisms of intracellular signal transduction are through coupling to $G_{i / o}$ proteins, which inhibits adenylate cyclase and decreases cyclic AMP production [1]. Opioid receptors and CB1 receptors are abundantly codistributed in the basal ganglia, caudate, putamen, dorsal hippocampus, amygdala, cerebellum, substantia nigra, nucleus accumbens, periaqueductal grey, and lamina II in the spinal cord [2]. Opioids and cannabinoids also share many pharmacologic properties, including hypothermia, sedation, hypotension, inhibition of intestinal motility, motor depression, antinociception, and reinforcement [3].

The results of the behavioral studies using selective opioid receptor antagonists, administered intracerebroventricularly or intrathecally, have suggested a major involvement of $\mu$-opioid peptide (MOP) receptors in the supraspinal cannabinoid antinociception [4]. Cross-tolerance was also demonstrated for the cannabinoids and $\kappa$-opioid peptide (KOP) agonists [5]. The results of in vitro studies suggested that high concentrations of $\mathrm{CB} 1$ antagonist act on MOP receptors in a $\mathrm{CB}_{1}$-independent manner [6]. From these shared properties and reports of in vitro and in vivo studies, opioid receptors and CB1 receptors can be cross-regulated, and there may be the possibility of functional links in the mechanisms of their actions.

Such results may suggest an interaction between opioids and cannabinoids at the level of receptor-ligand interactions and intracellular signal transduction mechanisms. Furthermore, antinociception, one of the shared pharmacologic properties of opioids and cannabinoids, particulary attract interest in their interactions. The present study investigated whether $\mathrm{CB}_{1}$ receptor-stimulated $\left[{ }^{35} \mathrm{~S}\right] \mathrm{GTP} \gamma \mathrm{S}$ binding is affected by selective opioid antagonists in the rat brain membranes. We found that activation of $\mathrm{G}$ proteins by the $\mathrm{CB}_{1}$ agonist, WIN55212-2, is not blocked by antagonizing the three subtypes of opioid receptors, indicating that there is no direct interaction between these receptors at least at the level of receptor-ligand interaction.

\section{Materials and Methods}

\section{Materials}

$\left[{ }^{35} \mathrm{~S}\right] \mathrm{GTP} \gamma \mathrm{S}(1,250 \mathrm{Ci} / \mathrm{mmol})$ was purchased from PerkinElmer Life Sciences (Boston, MA, USA). WIN55212-2 ((R)-(+)-[2,3dihydro-5-methyl-3-(4-morpholinylmethyl) pyrrolo [1,2,3-de]- 1,4-benzoxazin-6-yl]-1-naphthalenylmethanone mesylate), naloxone (NLX), nor-binaltorphimine (BNI), naltrindole (NTI), GTP $\gamma$ S, GDP, and all other chemicals were purchased from Sigma-Aldrich (St. Louis, MO, USA).

\section{Membrane preparation}

Membranes were isolated from the brains of twenty SpragueDawley rats (male), weighing 180-200 g. Rats were maintained in accordance with the University Committee on the Use and Care of Animals and the Guide for the Care and Use of Laboratory Animals. After euthanasia by intravenous thiopental sodium (100 mg/kg), each rat brain was rapidly excised and placed on dry ice before storage at $-70^{\circ} \mathrm{C}$. Subsequent handling of the tissues was performed at $4^{\circ} \mathrm{C}$. Brain tissues were meticulously dissected, washed in $50 \mathrm{mM}$ Tris- $\mathrm{HCl}$ buffer ( $\mathrm{pH}$ 7.4), and then disrupted for $1 \mathrm{~min}$ in ice-cold buffer with a Polytron homogenizer, set at a power of 6.5 (model PT-10; Brinkmann Instruments, Westbury, NY, USA). The homogenized membranes were centrifuged at $18,000 \mathrm{~g}$ for $15 \mathrm{~min}$. The resulting membrane pellets were resuspended and incubated at $37^{\circ} \mathrm{C}$ for $40 \mathrm{~min}$ to remove endogenous opioids [7]. The preparation was centrifuged again and the pellets resuspended in $50 \mathrm{mM}$ Tris- $\mathrm{HCl}$ buffer. Aliquots of this suspension were frozen at $-70^{\circ} \mathrm{C}$. The protein concentration of the rat brain membrane suspensions was approximately $7-8 \mathrm{mg} / \mathrm{ml}$, as determined by the Bradford assay with bovine serum albumin as the standard [8].

\section{$\left[{ }^{35} \mathrm{~S}\right] \mathrm{GTP} \gamma \mathrm{S}$ binding assay}

Agonist stimulation of $\left[{ }^{35} \mathrm{~S}\right] \mathrm{GTP} \gamma \mathrm{S}$ binding by WIN55,212-2 was measured as described in Traynor and Nahorski [9]. Membranes $\left(20-60 \mu \mathrm{g}\right.$ of protein/tube) were incubated in $\left[{ }^{35} \mathrm{~S}\right]$ GTP $\gamma$ S binding buffer (20 mM HEPES, pH 7.4, $100 \mathrm{mM} \mathrm{NaCl,}$ and $\left.10 \mathrm{mM} \mathrm{MgCl}_{2} \cdot 6 \mathrm{H}_{2} \mathrm{O}\right)$, containing $\left[{ }^{35} \mathrm{~S}\right] \mathrm{GTP} \gamma \mathrm{S}(0.1 \mathrm{nM})$, GDP $(100 \mu \mathrm{M})$, and varying concentrations $(3-30,000 \mathrm{nM})$ of WIN55212-2 in a total volume of $500 \mu \mathrm{l}$ for $60 \mathrm{~min}$ at $25^{\circ} \mathrm{C}$. Inhibition of agonist-stimulated $\left[{ }^{35} \mathrm{~S}\right] \mathrm{GTP} \gamma \mathrm{S}$ binding by NLX (20 nM), BNI (3 nM), or NTI ( $3 \mathrm{nM}$ ) was evaluated by adding the antagonist to the membrane 15 min before the addition of WIN55212-2. The reaction was terminated by rapidly filtering (Brandel cell harvester, Gaithersburg, MD, USA) through no. 32 glass fiber filters (Schleicher \& Schuell, Keene, NH, USA) and washing three times with $2 \mathrm{ml}$ of ice-cold GTP $\gamma \mathrm{S}$ binding buffer [10]. Filters were placed in scintillation vials with $4 \mathrm{ml}$ of Econo-Safe scintillation cocktail (Beckman Coulter, CA, USA) for liquid scintillation counting (Beckman LC6500, CA, USA). Basal binding was determined from tubes containing the same volume of $\left[{ }^{35} \mathrm{~S}\right] \mathrm{GTP} \gamma \mathrm{S}$ binding buffer without agonist or antagonist. Nonspecific binding was defined as the binding of 
$\left[{ }^{35} \mathrm{~S}\right] \mathrm{GTP} \gamma \mathrm{S}$ in the presence of $10 \mu \mathrm{M}$ unlabeled GTP $\gamma \mathrm{S}$. Because nonspecific binding was less than $5 \%$ of basal binding in this condition, the basal count per minute (cpm) was subtracted from each data point and converted to the percent over basal to determine agonist-stimulated $\left[{ }^{35} \mathrm{~S}\right] \mathrm{GTP} \gamma \mathrm{S}$ binding. All rat brain membrane experiments were performed at least twice, and each experiment was performed in duplicate.

\section{Data analysis}

$\left[{ }^{35} \mathrm{~S}\right] \mathrm{GTP} \gamma \mathrm{S}$ binding data from two experiments were combined and fit to a sigmoidal curve with a variable slope using GraphPad Prizm (Prism version 4.0, GraphPad Software, Inc., San Diego, CA, USA) to determine the $\mathrm{EC}_{50}$ value and maximum stimulation (\% over basal). Mean values (mean $\pm \mathrm{SEM}$ ) for the maximal stimulation of $\left[{ }^{35} \mathrm{~S}\right] \mathrm{GTP} \gamma \mathrm{S}$ binding and $\mathrm{EC}_{50}$ were calculated from six sets of independent experiments. The $K e$ values for antagonist inhibition were calculated using the following equation [11]: Ke = [nanomolar antagonist] / (dose ratio-1), where dose ratio is the ratio of the $\mathrm{EC}_{50}$ for WIN55212-2 in the presence and absence of each opioid antagonist.

\section{Results}

Optimal stimulation of $\left[{ }^{35} \mathrm{~S}\right] \mathrm{GTP} \gamma \mathrm{S}(0.1 \mathrm{nM})$ binding to the rat brain membranes by WIN55212-2 was observed at a concentration of $100 \mu \mathrm{M}$ GDP (data not shown). The value of mean \pm SEM for the maximal stimulation of $\left[{ }^{35} \mathrm{~S}\right] \mathrm{GTP} \gamma \mathrm{S}$ binding was $27.6 \pm 5.3 \%$ over basal in the rat brain membranes $(n=6)$. The value of $\mathrm{EC}_{50} \pm \mathrm{SEM}$ was $154 \pm 39.5 \mathrm{nM}(\mathrm{n}=6)$.

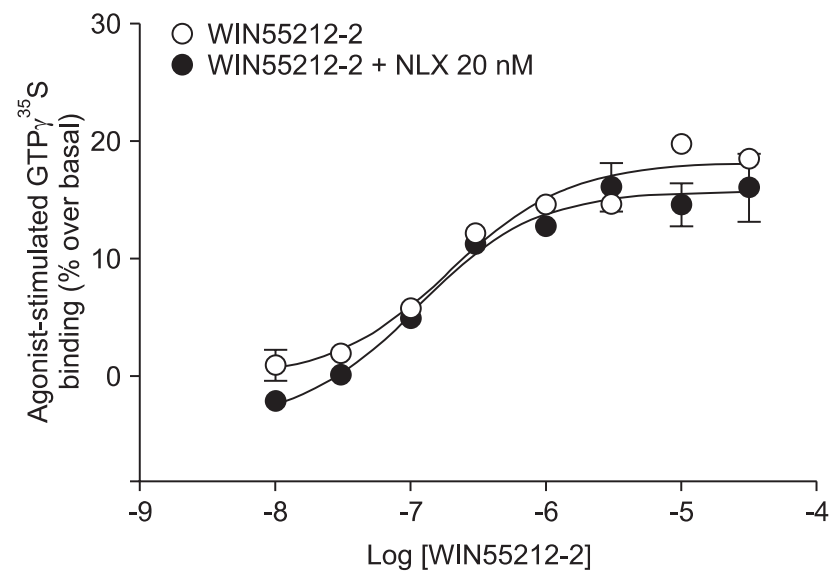

Fig. 1. Stimulation of $\left[{ }^{35} S\right]$ GTP $\gamma S$ binding by WIN55212-2 in rat brains. Concentration-response curves of WIN55212-2 were determined in the absence $(\bigcirc)$ or presence $(O)$ of $20 \mathrm{nM}$ of the $\mu$ opioid antagonist naloxone (NLX), as described in the Materials and Methods. The $\mathrm{EC}_{50}$ value of WIN55212-2 is $196 \mathrm{nM}$. In the presence of NLX $20 \mathrm{nM}$, the $\mathrm{EC}_{50}$ value of WIN55M212-2 is $111 \mathrm{nM}$. Mean values \pm SEM from two independent experiments performed in duplicate are shown.
Addition of a selective MOP antagonist at a low concentration (NLX $20 \mathrm{nM}$ ) did not produce a rightward shift in the WIN55212-2 concentration-response curve $\left(\mathrm{EC}_{50}=111 \mathrm{nM}, \mathrm{Ke}\right.$ $=-46.1$; Fig. 1). Addition of a selective KOP antagonist (BNI $3 \mathrm{nM}$ ) produced a 2.4-fold rightward shift in the WIN55212-2 concentration-response curve $\left(\mathrm{EC}_{50}=180 \mathrm{nM}, \mathrm{Ke}=2.1\right.$; Fig. 2). Addition of a selective $\delta$ opioid peptide (DOP) antagonist (NTI $3 \mathrm{nM}$ ) did not produce a rightward shift in the WIN55212-2 concentration-response curve $\left(\mathrm{EC}_{50}=224 \mathrm{nM}, \mathrm{Ke}=17.4\right.$; Fig. 3).

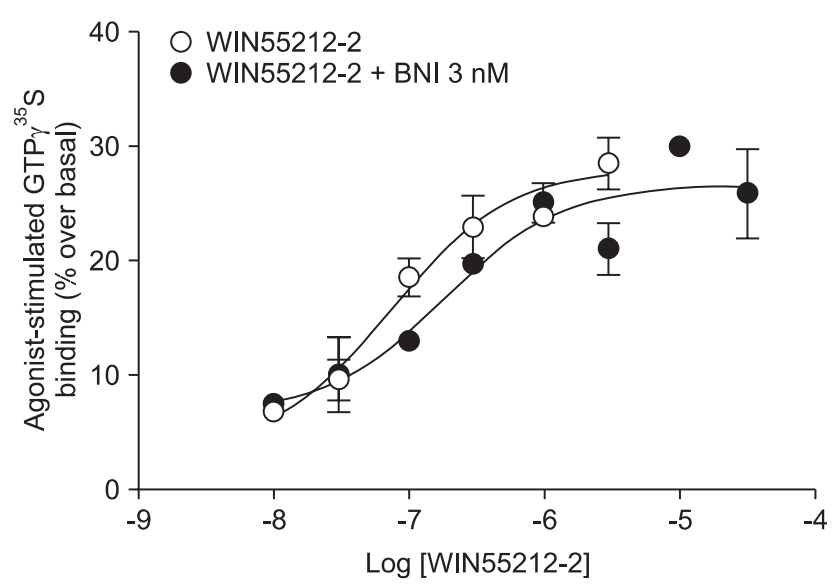

Fig. 2. Stimulation of $\left[{ }^{35} \mathrm{~S}\right] \mathrm{GTP} \gamma \mathrm{S}$ binding by WIN55212-2 in rat brains. Concentration-response curves of WIN55212-2 were determined in the absence $(\bigcirc)$ or presence $(O)$ of $3 \mathrm{nM}$ of the $\kappa$ opioid antagonist nor-binaltorphimine (BNI), as described in the Materials and Methods. The $\mathrm{EC}_{50}$ value of WIN55212-2 is $75 \mathrm{nM}$. In the presence of BNI $3 \mathrm{nM}$, the $\mathrm{EC}_{50}$ value of WIN55M212-2 is $180 \mathrm{nM}$. Mean values \pm SEM from two independent experiments performed in duplicate are shown.

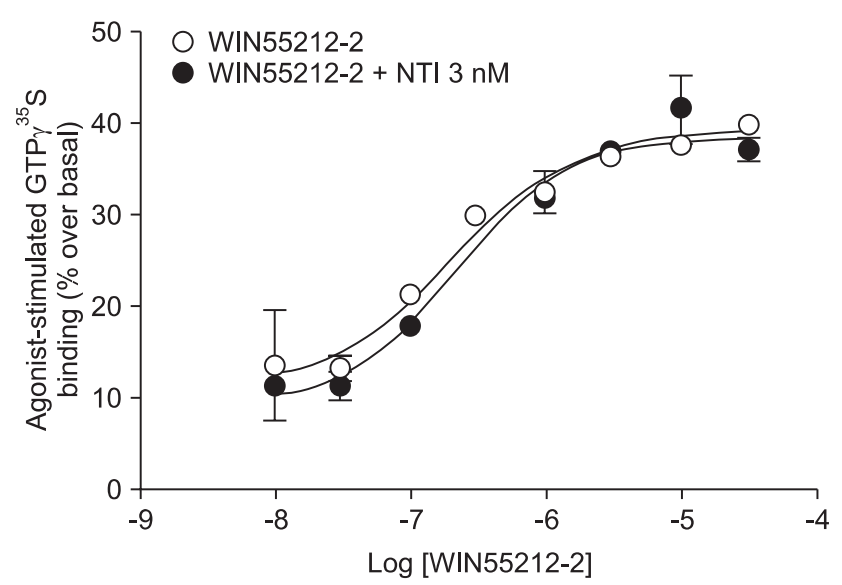

Fig. 3. Stimulation of $\left[{ }^{35} \mathrm{~S}\right] \mathrm{GTP} \gamma \mathrm{S}$ binding by WIN55212-2 in rat brains Concentration-response curves of WIN55212-2 were determined in the absence $(\bigcirc)$ or presence $(-$ ) of $3 \mathrm{nM}$ of the $\delta$ opioid antagonist naltrindole (NTI), as described in the Materials and Methods. The $\mathrm{EC}_{50}$ value of WIN55212-2 is $191 \mathrm{nM}$. In the presence of NTI $3 \mathrm{nM}$, the $\mathrm{EC}_{50}$ value of WIN55212-2 is $224 \mathrm{nM}$. Mean values \pm SEM from two independent experiments performed in duplicate are shown. 


\section{Discussion}

Similarities in the receptor distributions and pharmacological characteristics between opioids and cannabinoids have been demonstrated. The expression patterns of MOP receptors and CB1 receptors overlap in several areas of the central nervous system. In regions such as caudate, putamen, the dorsal hippocampus, and the nucleus accumbens, MOP and CB1 receptors are co-expressed in the same neurons [12,13]. Thus, possible interactions between opioids and cannabinoids have been suggested, and they have been investigated at receptorligand interaction and intracellular signal transduction level $[5,6]$. It has also been demonstrated that cross-regulation between MOP and CB1 may occur through a direct interaction [14]. However, based on the above evidence, there are additional unidentified receptor-ligand interactions and intracellular signal transduction mechanisms that need to be clarified between the MOP and CB1 receptors.

It was observed that the functional maximal activities of agonist-stimulated $\left[{ }^{35} \mathrm{~S}\right] \mathrm{GTP} \gamma \mathrm{S}$ binding by WIN55212-2 are $27.6 \pm$ $5.3 \%$ over basal (mean $\pm \mathrm{SEM}, \mathrm{n}=6$ ). Others have reported that the functional maximal activities are up to $80 \%$ over basal [15]. In these studies, however, human embryonic kidney 293 (HEK-293), Neuro-2A, or human neuroblastoma cells (SK-N-SH) were used to prepare the membrane fractions for the $\left[{ }^{35} \mathrm{~S}\right] \mathrm{GTP} \gamma \mathrm{S}$ binding assays [15]. As such, the variations may have come from the different types of the membranes used. The type of membrane denotes the densities of $\mathrm{CB} 1$ receptors in specific membranes, the functional power of biologic milieu for the activation of $\left[{ }^{35} \mathrm{~S}\right] \mathrm{GTP} \gamma \mathrm{S}$ binding. The $\mathrm{EC}_{50}$ value (mean $\pm \mathrm{SEM}$ ) of the concentration-response curve by WIN55212-2 was $154 \pm 39.5$ $\mathrm{nM}$, which was consistent with the findings of other studies [15]. Two to three fold higher concentrations of WIN55212-2 were needed for rat brain membranes.

CB1 receptors are well known to be closely related to opioid receptors in terms of antinociception (MOP receptors in particular), and studies of both receptors have revealed the existence of bidirectional cross-tolerance $[16,17]$ and crossaddictive effects between opioids and cannabinoids [18]. Furthermore, CB1 receptors form multimers, as they do in various other G-protein coupled receptors [17]. Although only the homodimeric form of CB1 multimer has been found thus far, CB1 receptor may be a potential partner for association with opioid receptors [19]. In the present study, selective opioid antagonists [NLX (20 nM) as a selective MOP antagonist, BNI (3 $\mathrm{nM})$ as a selective KOP antagonist, and NTI ( $3 \mathrm{nM})$ as a selective DOP antagonist] were used to investigate the involvement of opioid receptors at the level of receptor-ligand interaction and intracellular signal transduction. The antagonist results showed no significant rightward shift of the concentration-response curve by WIN55212-2-stimulated $\left[{ }^{35} \mathrm{~S}\right] \mathrm{GTP} \gamma \mathrm{S}$ binding (Fig. 1, 2 and 3). In addition, the Ke values for inhibition of each opioid antagonist were not applicable. When a fixed dose of selective opioid antagonist is used in our experiment with graded doses of WIN55212-2, it is possible to determine the affinity of the antagonist $(\mathrm{Ke})$ for the $\mathrm{CB} 1$ receptors [11]. Adding high dose of NLX, in a concentration that nonselectively antagonizes all three opioid receptors (200 $\mathrm{nM}$ ), did not result in a rightward shift in the concentration-response curve (data not shown).

Taken together, agonist-stimulated $\left[{ }^{35} \mathrm{~S}\right] \mathrm{GTP} \gamma \mathrm{S}$ binding by the CB1 agonist WIN55212-2 was not affected by selective opioid antagonists in the rat brain membranes. Though several studies have described the functional interactions between opioids and cannabinoids at the cellular and behavioral levels, the present results suggest that the functional activity of WIN55212-2 have not been influenced by opioid antagonists at the level of receptor-ligand interaction and intracellular signal transduction. Although complete understanding of the exact mechanism remains unclear, the results may partially elucidate their actions.

\section{References}

1. Demuth DG, Molleman A. Cannabinoid signalling. Life Sci 2006; 78: 549-63.

2. Manzanares J, Corchero J, Romero J, Fernández-Ruiz JJ, Ramos JA, Fuentes JA. Pharmacological and biochemical interactions between opioids and cannabinoids. Trends Pharmacol Sci 1999; 20: 287-94.

3. Howlett AC, Breivogel CS, Childers SR, Deadwyler SA, Hampson RE, Porrino LJ. Cannabinoid physiology and pharmacology: 30 years of progress. Neuropharmacology 2004; 47(Suppl 1): 345-58.

4. Reche I, Fuentes JA, Ruiz-Gayo M. A role for central cannabinoid and opioid systems in peripheral delta 9-tetrahydrocannabinolinduced analgesia in mice. Eur J Pharmacol 1996; 301: 75-81.

5. Meng ID, Manning BH, Martin WJ, Fields HL. An analgesia circuit activated by cannabinoids. Nature 1998; 395: 381-3.

6. Cinar R, Szücs M. CB1 receptor-independent actions of SR141716 on G-protein signaling: coapplication with the mu-opioid agonist Tyr-D-Ala-Gly-(NMe)Phe-Gly-ol unmasks novel, pertussis toxininsensitive opioid signaling in mu-opioid receptor-Chinese hamster ovary cells. J Pharmacol Exp Ther 2009; 330: 567-74.

7. Wood MS, Rodriguez FD, Traynor JR. Characterisation of kappa-opioid binding sites in rat and guinea-pig spinal cord. Neuropharmacology 1989; 28: 1041-6.

8. Bradford MM. A rapid and sensitive method for the quantitation of microgram quantities of protein utilizing the principle of proteindye binding. Anal Biochem 1976; 72: 248-54.

9. Traynor JR, Nahorski SR. Modulation by mu-opioid agonists of guanosine-5'-O-(3-[35S]thio)triphosphate binding to membranes from human neuroblastoma SH-SY5Y cells. Mol Pharmacol 1995; 47: 848-54.

10. Clark MJ, Traynor JR. Endogenous regulator of G protein signaling proteins reduce $\{\mathrm{mu}\}$-opioid receptor desensitization and down- 
regulation and adenylyl cyclase tolerance in C6 cells. J Pharmacol Exp Ther 2005; 312: 809-15.

11. Tallarida RJ. Drug synergism and dose-effect analysis. Washington D.C., Chapman \& Hall/CRC. 2000, pp 143-54.

12. Pickel VM, Chan J, Kash TL, Rodríguez JJ, MacKie K. Compartmentspecific localization of cannabinoid 1 (CB1) and mu-opioid receptors in rat nucleus accumbens. Neuroscience 2004; 127: 101-12.

13. Salio C, Fischer J, Franzoni MF, Mackie K, Kaneko T, Conrath M. CB1-cannabinoid and mu-opioid receptor co-localization on postsynaptic target in the rat dorsal horn. Neuroreport 2001; 12: 368992.

14. Hur EM, Kim KT. G protein-coupled receptor signalling and crosstalk: achieving rapidity and specificity. Cell Signal 2002; 14: $397-$ 405.

15. Rios C, Gomes I, Devi LA. Mu opioid and CB1 cannabinoid receptor interactions: reciprocal inhibition of receptor signaling and neuritogenesis. Br J Pharmacol 2006; 148: 387-95.

16. Thorat SN, Bhargava HN. Evidence for a bidirectional crosstolerance between morphine and delta 9-tetrahydrocannabinol in mice. Eur J Pharmacol 1994; 260: 5-13.

17. Rubino T, Tizzoni L, Viganò D, Massi P, Parolaro D. Modulation of rat brain cannabinoid receptors after chronic morphine treatment. Neuroreport 1997; 8: 3219-23.

18. Smith FL, Cichewicz D, Martin ZL, Welch SP. The enhancement of morphine antinociception in mice by delta9-tetrahydrocannabinol. Pharmacol Biochem Behav 1998; 60: 559-66.

19. Wager-Miller J, Westenbroek R, Mackie K. Dimerization of G protein-coupled receptors: $\mathrm{CB} 1$ cannabinoid receptors as an example. Chem Phys Lipids 2002; 121: 83-9. 